\title{
Duvar Resimlerinde Bir Taşra Örneği: Samsun Kefeli Apartmanında İki Duvar Resmi
}

\section{Özet}

Duvar resim geleneğinin Osmanlı resim sanatı içindeki oluşum ve gelişim evrelerini XVIII. yüzyıldan itibaren takip etmek mümkündür. Lale Devri olarak da adlandırılan ve Batılılaşma çizgisinin başlangıc olarak kabul edilen dönemde ortaya çıkan duvar resim geleneğinin kısa süre içinde saray sınırlarını aşıp Anadolu'nun farklı konut ve sivil eserlerinde vücut bulduğu bilinmektedir. XIX. yüzyılda konutlardan camilere ve şadırvanlara kadar farklı yapı tiplerinde duvarları süsleyen söz konusu resimlerin XX. yüzyılda da gelişimini sürdürdüğü ve hatta Cumhuriyet dönemi içinde uygulama alanı bulduğu çeşitli örneklerde görülmektedir. Bu bağlamda çalışmada ele alınan Samsun'daki Kefeli Apartmanının giriş örneklerde görülmektedir. Bu bağlamda çalışmada ele alınan Samsun'daki Kefeli Apartmanının giriş̧
holünde yer alan iki duvar resmi, Osmanlı duvar resim sanatının XX. yüzyıldaki gelişimi çerçevesinde değerlendirilecek, kentin apartmanlaşma süreci içinde gelenekten elde ettiği deneyimler bağlamında söz konusu resimler irdelenecektir.

Anahtar Kelimeler: Osmanlı Resim Sanatı, Duvar Resimleri, Apartman, Konut

A PROVINCIAL EXAMPLE OF WALL PAINTINGS:

TWO WALL PAINTINGS IN SAMSUN KEFELI APARTMENT

\section{Abstract}

It is possible to follow the formation and development of the wall painting in Ottoman painting art from the 18th century. It is known that the tradition of mural painting, which emerged in the period, which is also known as the Tulip Age and accepted as the beginning of the westernization line, crossed the palace boundaries in a short time and came into existence in different residential and civil works of Anatolia. It is seen in various examples that these paintings, which adorn the walls and civil works of Anatolia. It is seen in various examples that these paintings, which adorn the walls
in different building types from houses to mosques and fountains in the 19th century continued to develop in the 20th century and even found implementation in the Republic period. In this context, the two wall paintings in the entrance hall of the Kefeli Apartment in Samsun will be evaluated within the framework of the development of the Ottoman wall painting in the 20th century, and these paintings will be examined in the context of the experiences the city has gained from the tradition during the apartmentization process.

Keywords: Ottoman Painting Art, Wall Painting, Apartment, Dwelling 


\section{Giriş}

XVIII. yüzyıldan itibaren Osmanlı sanatı ve mimarisinde görülen Batı eksenli değişim ve dönüşüm çabası, küçük bir odanın resim programından büyük boyutlu külliye tasarımına kadar hemen her alanda kendisini göstermektedir. Ahmet Refik tarafından "Lale Devri" olarak adlandırılan ve Batı'ya bakış açısının değişimini yansıtan III. Ahmet dönemi, pek çok sanat ve mimarlık tarihçisi tarafından bu değişim ve dönüşümün başlangıç noktası olarak kabul edilmektedir. Yüzyılın ortalarına doğru form değiştiren ve mimari programa dâhil edilen Barok tasarımların Kuban ve Eyice tarafından "Türk Baroğu" şeklinde tanımlanması, sanat tarihi yazımını uzun bir süre Batıılıaşma döneminin Osmanlı sanatında kabulü ve içselleştirilmesi yönünde yorumlara sevk etmiştir (Kuban, 1954:135-136; Eyice, 1981:164-166). Benzer bir tutumun Renda tarafından duvar resimleri üzerinden sürdürüldüğü söylenebilir. Duvar resim geleneğinin XVIIII. yüzyılda başladığı ve ilk örneklerini Topkapı Sarayı'nda verdiği bilinmektedir. Bununla birlikte çok kısa bir süre içinde Anadolu ve Balkan coğrafyasına yayılan duvar resimlerinin Barok ve Rokoko üsluplarılla bir arada kullanıldığı dile getirilmektedir (Renda, 1977:77-78). Minyatür sanatında görülen değişim ve üçüncü boyut arayışlarının Osmanlı sanatçıarını manzara resimlerine yönlendirdiği ve bunların da duvar resimleriyle vücut bulduğunu aktaran Renda, manzara konusunun minyatür sanatındaki geçmişine vurgu yaparak figüratif öğelerden üçüncü boyut aktarımında belli bir süre uzak durulmasının sebepleri arasında söz konusu tarihsel geçmişin varlığını dile getirmektedir (Renda, 1977:199-201)

Temalarını doğa ve kent temelli manzaralardan alan duvar resimlerinde figüratif öğelerin kullanım alanlarııı kısıtı olduğu görülür. Resmedilen kent manzaraları İmparatorluğun başkenti İstanbul ve çevresi olabileceği gibi (Demirarslan, 2016:113-122) Mekke (Kâbe) ve Medine gibi kutsal topraklarda bulunan kentlerin de duvar resimlerinde sıklıkla tercih edildiği gözlenir (Uğurlu, 2020:192-196). Birgi Çakırağa Konağı, Datça Mehmet Ali Konağı, Amasya Sultan II. Bayezid Camii Şadırvanı ve Merzifon Paşa Camii Şadırvanı İstanbul temalı kent manzara örnekleri sunan duvar resimlerine sahip Anadolu örneklerini oluşturmaktadır (Arık, 1976:120). Konumu tanımlanabilen söz konusu manzara resimleri dışında hayali olarak tanımlanan, hangi kentin resmedildiği belirlenemeyen örnekler de duvar resimleri arasında yer almaktadır. Anadolu'da pek çok konut ve dini eserlerin duvarlarını süsleyen kent manzaralarına, ölü doğa konulu çiçek ve meyve motiflerinin eşlik ettiği görülmektedir. Sanatçılarının genellikle anonim kaldığı duvar resimlerinde görülen gerçekçi İstanbul tasvirleri, sanatçıların bir kısmının İstanbul'dan sipariş üzerine Anadolu ve Balkan kentlerine intikal etmiş olabileceğini düşündürebilir. Mevcut veriler ışı̆̆ında sanatçıların bir kısmının hangi kentten geldikleri ve hangi millete mensup oldukları tespit edilmiştir. Zileli Emin, Seyhzade Abdurrahman Efendi, Ali Miralaygil, Mucurlu Nakkaş Hacı Ahi, Şemsi Mehmet, BağdasaryanNerses ve Hagopcan Mahsereciyan gibi isimler, Anadolu'da duvar resimlerini icra eden sanatçıların bir kısmını oluşturmaktadır. Söz konusu ustaların gerek gayrimüslim tebaadan gerekse Müslüman tebaadan oldukları, bununla birlikte özellikle ittalyan ressamların da Anadolu'da duvar resimleri üzerine sipariş aldıkları bilinmektedir (Uğurlu, 2020:200-206). Konutların duvar ve tavanlarını süsleyen duvar resimlerinin Anadolu'daki yayılımı yapılan akademik çalışmalarla hatırısayılır bir envanter birikimi neticesinde izlenebiliyor olmasına karşın Cumhuriyet döneminin ilk yıllarında Anadolu kentlerinde hızla yaygınlaşan apartmanların giriş hollerini ve koridor duvarlarını süsleyen duvar resimleri hakkındaki bilgilerimiz oldukça sınırlıdır (Karaaslan, 2021:74).

XIX. yüzyılda Osmanlı resim sanatında görülen değişim ve dönüşüm, sivil mimaride de izlenmektedir. Özellikle başkent İstanbul'un levanten bölgesi Pera ve Galata'da yoğunlaşan kentsel dönüşüm, konut mimarisinde apartmanlaşma eğilimi göstermekte (Görgülü, 2016:167-168; Tezer, 2017:18), inşa edilen çok katlı apartman dairelerinde yabancı misafirler ve gayrimüslim tebaadan aileler ikamet etmektedir (Derin Öncel, 2014:229). Uzun bir süre boyunca Müslüman yoğunluğa sahip semtlerde tercih edilmeyen apartmanların ancak XX. yüzyılın ilk çeyreğinde bu bölgelerde yükseldiği bilinmektedir. Bu dönemde yüksek konfor ve lüks olarak algılanan apartman yaşamına paralel olarak İstanbul'un gelişim gösteren yeni cazibe merkezleri Taksim, Nişantaşı, Kadıköy, Moda ve Yeşilköy gibi semtlerde genellikle apartman tarzı konut tipinin tercih edildiği görülür (Özakbaş, 2015:295; Akın, 2010: 22-24). Ankara'nın başkent ilan edilmesiyle birlikte yoğun inşaat faaliyetlerine sahne olan kentte apartmanlaşmanın 1930'lu ve 1940 'I yıllarda yaygınlaştığı görülmektedir. Emlak vergisinde indirim sağlanması gibi teşviklerde bulunan devletin bu yıllarda inşaat sektörüne destek sağlamasıyla özel sektörün apartman tipi konut üretimine yöneldiği söylenebilir. Modern çizgide tasarlanan söz konusu apartmanların özellikle cephe biçimlenişinde İstanbul örneklerinden farklı olduğu, Ankara'nın modern/kübik yönelimine nazaran İstanbul'un farklı üsluplara açık bir kent oluşu Tezer tarafından dile getirilmektedir (Tezer, 2017:33). Söz konusu yıllarda i̇stanbul ve Ankara'nın dışında, Anadolu'nun gelişmekte olan pek çok kentinde apartman tarzı konut tercihi görülmektedir. Artan nüfus ve eski tip konut uygulamalarının yavaşlamasıyla özellikle 1929 sonrası hız kazanan apartman tipi konut üretiminin, başkent Ankara ve İstanbul dışında genellikle memur ve bürokrat kesimin tercih ettiği, kentin istasyona açılan 
ana caddeleri üzerinde yoğunlaştığı söylenebilir (Aslanoğlu, 2010:80-81). Genellikle mal sahibinin adını taşıyan apartmanlar, dönemin bilinen mimarları tarafından tasarlanıyor ve bu durum mal sahibine prestij kazandırabiliyordu (Bozdoğan, 2008:245). Kimi yapılar ise dönemin ilk mimarlık dergisi Mimar'da tanıtılmakta, eserlerin müellifleri yapılarını modernist söylemler üzerinden tanımlamaktadır. Aynı zamanda konforu ve çağdaşlı̆ıı simgeleyen söz konusu apartmanlar için mobilya ve mekân dekorasyonu ile ilgili haberlere de yer verilmektedir.

XIX. yüzyılda kentsel ölçekte önemli gelişim kat eden Samsun'un, XX. yüzyılla birlikte sahip olduğu liman vasıtasıyla hinterlandını genişlettiği ve bir liman kenti hüviyetine sahip olduğu görülür (Topal, 2006:327-328). Geç XIX. yüzyıl ile XX. yüzyılın ilk çeyreğinde kentte inşa edilen kamu eserleriyle birlikte, çıkan yangınlar sonucunda yeniden şekillenen mahallelerde yükselen konut tipleri kentin siluetini değiştirmiş, modern bir kent görünümü yaratılmışır (Duymaz, 2006:452-453). Özellikle 1927 yılında Samsun-Amasya demiryolu hattının açımasıyla Anadolu'ya bağlanan Samsun limanı gerek kentin ticari faaliyetlerinde gerekse nüfus artışında ve kentsel gelişiminde önemli değişimler meydana getirmiştir. Şüphesiz 1930 'lu yıllarda Anadolu kentlerinde görülmeye başlayan apartmanlaşma eğiliminin, yukarıda sıraladığımız nedenlerden ötürü Samsun'da da etkil olduğu düşünülebilir. İhmalkâr bir şekilde bakımsız kalan, yerel yönetimler vasıtasıyla yıkım kararı alınıp günden güne sayısı azalan söz konusu erken Cumhuriyet dönemi apartmanlarının arasında Kefeli Apartmanı, cephe ve plan özelliklerinin yanında giriş holünde bulunan ve araştırmamızın ana temasını oluşturan duvar resimleri ile Samsun'un mimari tarihi içinde özel bir yere sahiptir.

\section{Kefeli Apartmanı ve Duvar Resimleri}

İlkadım İlçesi, Kale Mahallesi, Cumhuriyet Caddesi üzerinde yer alan Kefeli Apartmanı, bulunduğu konumu sebebiyle XIX. yüzyılda gelişim gösteren kent sınırları içinde bulunmaktadır. XX. yüzyılın başlarında inşası tamamlanan Hükümet Konağı (Bayraktar, 2016:360) ile aynı cadde üzerinde yer alan Kefeli Apartmanının inşa tarihi kesin olarak bilinmemekte, Hakkı Kefeli adında bir şahsın girişimiyle inşa edildiği dile getirilmektedir ${ }^{1}$. Hakkı Kefeli ile ilgili herhangi bir belgeye rastlanmamasına karşın 1929 tarihli Annuaire Oriental'de Samsun'da tütün ticareti yapan tüccarlar arasında Kefelizade Halim Efendi isminde bir tüccara rastlanmıştır (Rizzo, 1929:1068). Kefelizade Halim Efendi'nin, Kefeli Apartmanıyla bağı ise mevcut verilerle çözümlenemeyecek durumdadır. 1932 yılında Atı Atatürk Heykeli'nin dikildiği (Osma, 2003:70-75), kentin simge kamusal alanlarından Gazi Parkı'na bakan ana cephesiyle değerli bir konuma sahip söz konusu eserin inşa tarihi kesin olarak belirlenemese de gerek plan ve cephe özellikleri gerekse araştırma konumuzun ana temasını oluşturan duvar resimleri üzerinde yer alan tarih üzerinden yapının inşa tarihi hakkında çıkarım yapmak mümkün görünmektedir.

XIX. yüzyılın sonlarından itibaren özellikle başkent İstanbul'da Galata-Pera Bölgesinde yoğunluk gösteren apartmanların Neo Klasik ve Art Nouveau ağırlıklı cephe özelliklerine sahip olduğu bilinmektedir. 1930'lu yıllardan itibaren İstanbul apartmanlarının üslup çeşitliliğine Art Deco ve kübik mimari etkili eserlerin de katılmıs olduğu görülmektedir ve böylece Ankara'da söz konusu yıllarda özellikle konut mimarisinde yoğunluk kazanan modern tasarım semalarının İstanbul'u da etkisi altına aldığı söylenebilir (Bozdoğan, 2008:252). Bitişik nizamlı çift cepheli Kefeli apartmanının cephe şemasında sahip olduğu tasarım detaylarına baktığımızda 1930'lu yıllarda İstanbul'da inşa edilen Art Deco ağırlıklı apartmanlar (Özakbaş, 2015:305) ile benzer kütle özelliklerine sahip olduğunu söyleyebiliriz (Görsel 1-2).Geniş pencere açıklıkları ve söz konusu açıklıklarda kullanılan kırık kemer hareketliliği ve Neo Klasik üsluba atıfta bulunan fugalarla yatay olarak bölümlenen plaster kullanımı, betonarme iskeletli Kefeli Apartmanının 1930'lu yılların İstanbul'unda yükselen apartmanlarla benzer tasarım özelliklerini paylaştığını göstermektedir. Giriş holünün iki yanında kartonpiyer çerçeveler içinde bulunan iki resimde de görülen 1934 tarihi, muhtemelen resimlerin bitirildiği tarihe işaret etmektedir. Söz konusu duvar resimlerinin apartman inşasının bitimiyle birlikte tamamlandığı düşünülürse Kefeli Apartmanının 1930-1934 yılları arasında inşa edilmiş olabileceği söylenebilir.

Dikdörtgen bir kartonpiyer çerçeve içinde birbirine bakan aynı ölçülere sahip iki duvar resminin İstanbul'dan gelen Kemal adlı bir ressam tarafından 1934 'te tamamlandığı her iki resimde yer alan imzadan anlaşımaktadır. Birinci resim olarak adlandıracağımız, giriş holünde sağ duvarda bulunan duvar resmi, aslında XIX. yüzyıl asker ressamların üretmis olduğu eserlerden bu yana gerek tablolarda gerekse mimariye dahil edilen duvar resimlerinde sıklıkla tercih edilen manzara konusuna sahiptir (Görsel 3). Ön planda, bir kısmı dere/göl kıyısında biriken ve su içen bir kısmı ise yamaca doğru yönelmiş koyun sürü ile derenin/gölün diğer yakasında elinde asas ile koyunlara doğru yönelmiş uzun beyaz sakallı çoban ve yanındaki köpeği görülmektedir. Arka planı ise yaprakları sararmış oldukça büyük bir ağaç kümesi ile gerisinde yoğun bulut kümesi kaplamaktadır. 

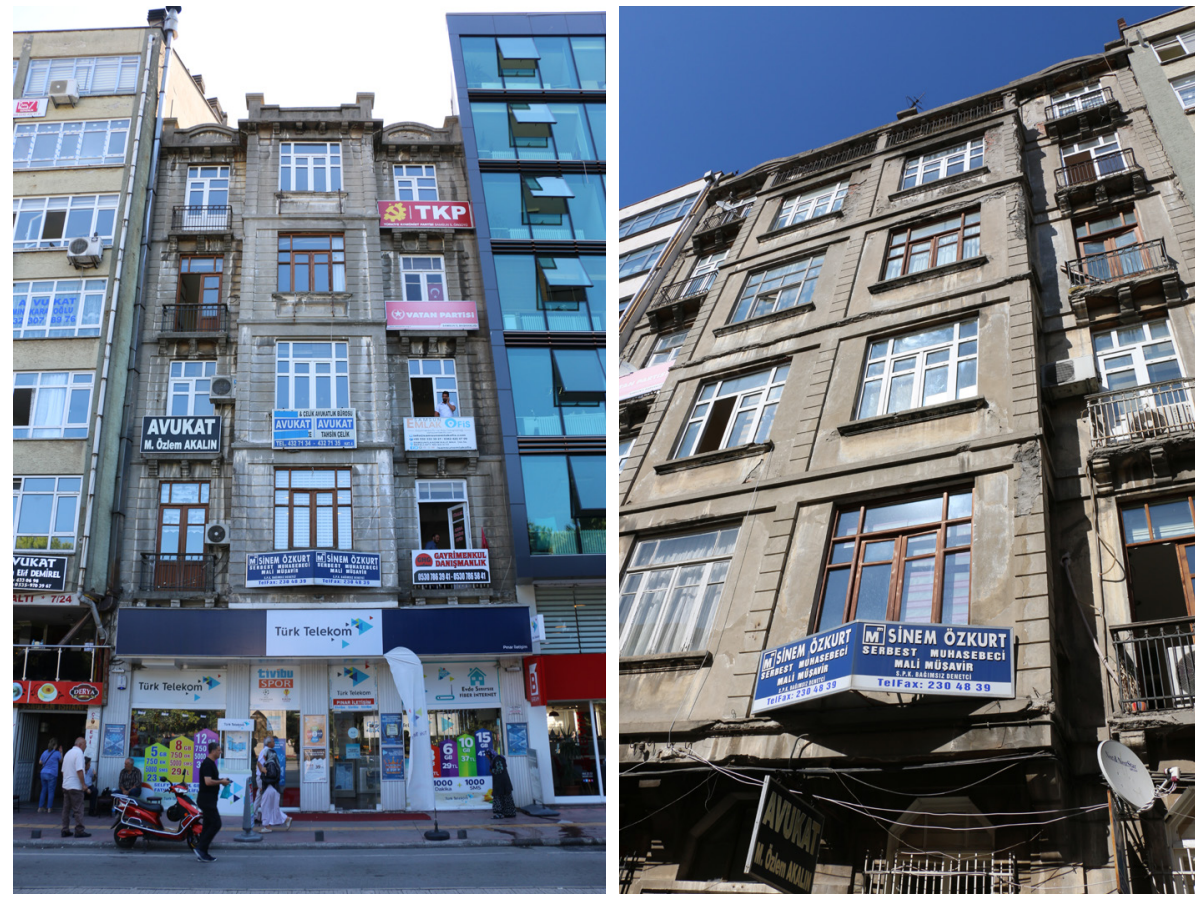

Görsel I. Kefeli Apartmanı, Gazi Parkına Bakan Cephesi (E. Kolay, 20I8) (Solda) Görsel 2. Kefeli Apartmanı, Giriş Cephesi (E. Kolay, 2018) (Sağda)

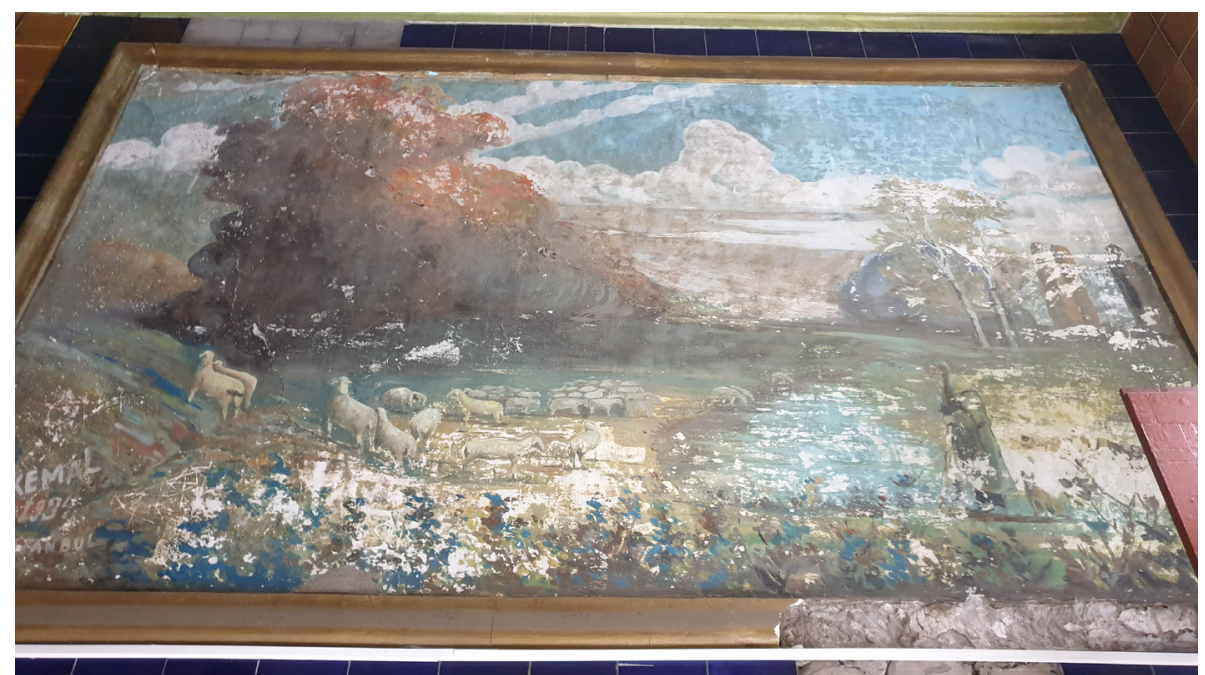

Görsel 3. Giriş Holü Sağ Duvarında Kalan Duvar Resmi (E. Kolay, 2020)
İkinci resim olarak adlandırabileceğimiz giriş holünün sol duvarında diğer duvar resmi ile aynı boyutlara sahip manzara resminde daha tanıdık bir manzara ile karşılaşmaktayız (Görsel 4). Resmin ön planında gövdesi ve yaprakları ile resimde oldukça geniş yer bulan ağaç görülmektedir. Arka plana baktığımızda ise, manzaraya bir tepeden bakıldığı anlaşılır; sakin bir deniz ve kıyıya yanaşmakta olan yandan çarklı bir vapur resmin arka planında seçilen birtakım unsurlardır. Bununla birlikte vapurun yanaşmakta olduğu iki katlı ve kırmızı çatısıyla iskele binası ve hemen önündeki yelkenli, resim arka planında dikkat çeken öğelerdir. Daha derinlerde ise detayları verilmemiş fakat yelkenleri seçilebilen bir tekne de resmin arka planında hareketliliğe katkı sağlamıştır. Resmin tüm detayları incelendikten sonra söz konusu manzaranın aslında M. VedadTek'in1910'lu yılların sonunda inşa ettiği Moda İskelesi'ni (Batur, 2003:158-159) konu edinen bir fotoğraftan aktarıldığını söyleyebiliriz. İ.B.B. Atatürk Kitaplığı'nın fotoğraf arşivinde yer alan bir fotoğraf (Atatürk Kitaplığı, Katalog No: Krt 016322), yukarıda betimlediğimiz manzara resmi ile birebir uyuşmaktadır (Görsel 5).

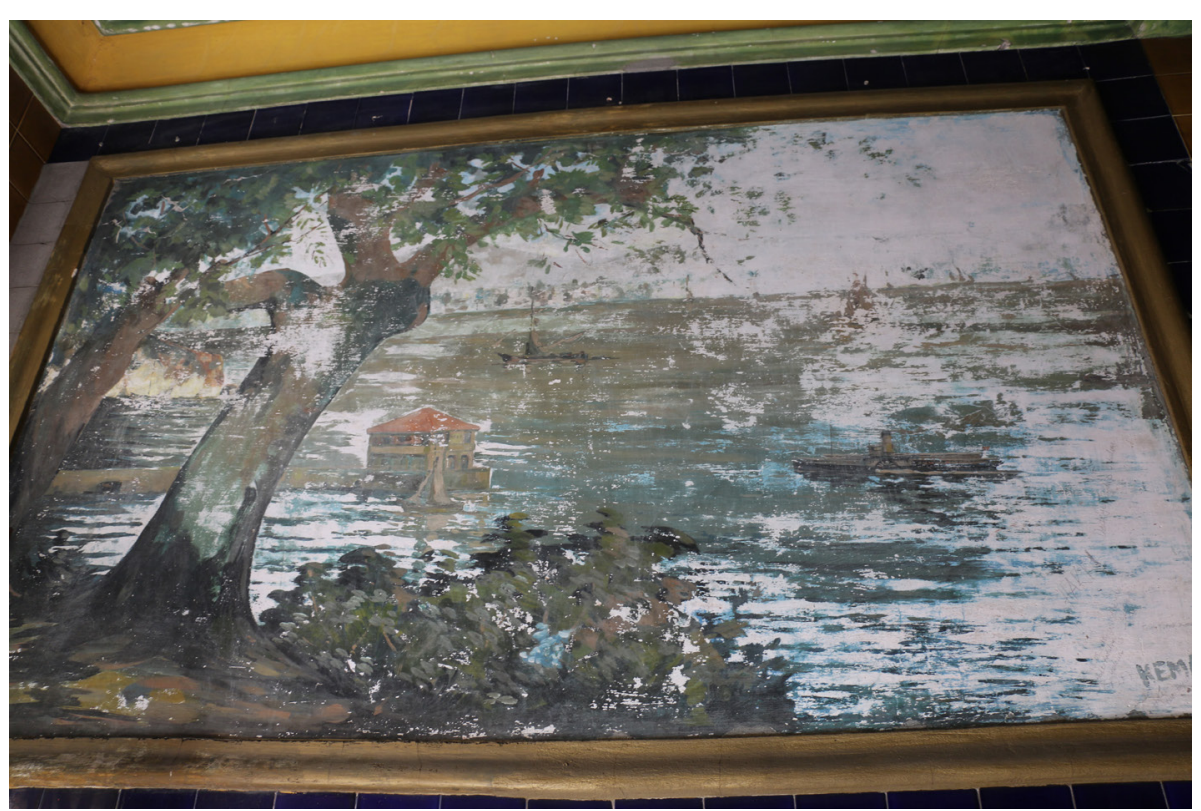

Görsel 4. Giriş Holü Sol Duvarında Kalan Duvar Resmi (E. Kolay, 2020) 


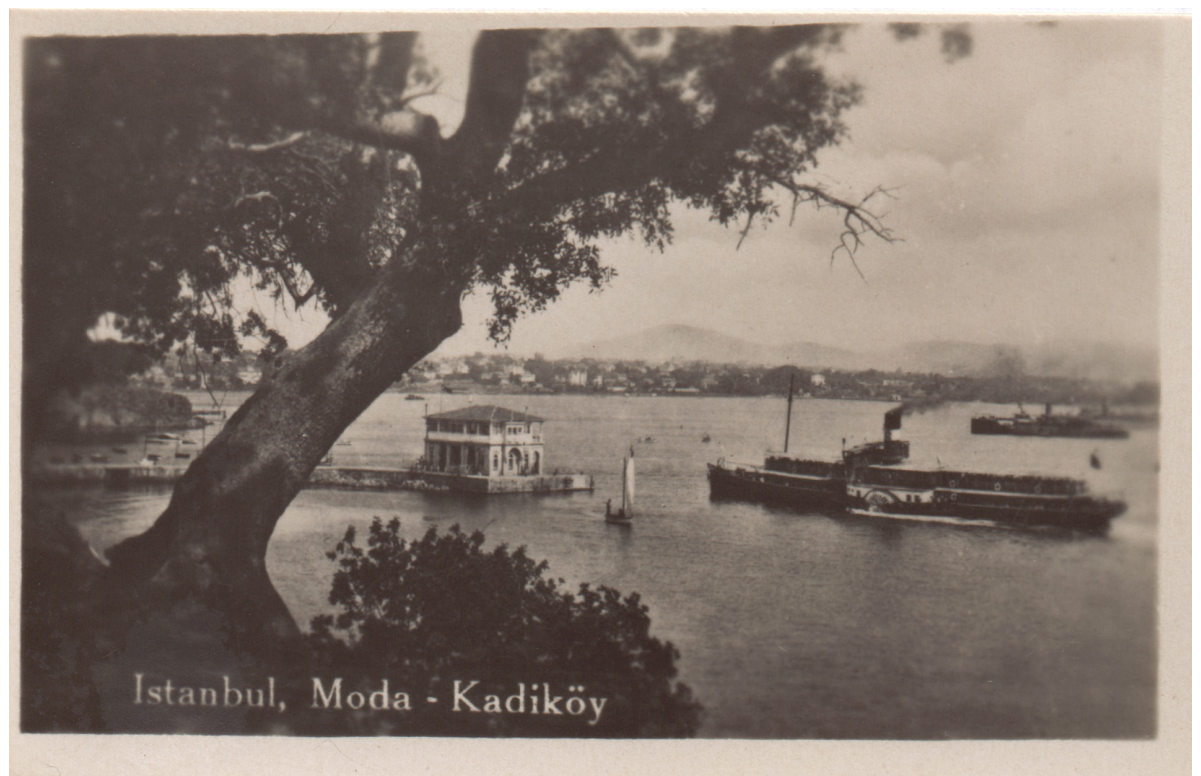

Görsel 5. I. B.B. Atatürk Kitaplığı Arşivinde Moda İskelesi'ni Konu Edinen Fotoğraf (I.B.B. Atatürk Kitaplığı, Krt_0I6322)

\section{Sonuç Yerine}

Kefeli Apartmanında ele alınan duvar resimlerinin benzer örneklerini kültürel ve sanatsal faaliyetlerin daha yoğun yaşandığı İstanbul'da görmek mümkündür. Özellikle Türkiye'de apartmanlaşmanın ilk örneklerinin görüldüğü Beyoğlu semtinde karşımıza çıkan duvar resimlerine Taksim'de Eden Apartmanı, Rita Apartmanı, Sakin Apartmanı, Ege Apartmanı, Şen Yuva Apartmanı, Sarper Apartmanı ve Feridiye Apartmanı, Cihangir'de Ender Apartmanı, Demir Apartmanı ve Platin Apartmanında rastlamak mümkündür (Pınarbaşı, 2004:180-184). Kefeli Apartmanında yer alan iki duvar resminin Samsun ve çevresinde şu ana dek örneğine rastlanmamışıtır. Erken Cumhuriyet dönemi apartmanlarının günden güne azalması ve kent siluetindençekilmesisebebiyle apartmanlarıniçmekanlarını hareketlendiren duvar resmi ve benzeri süsleme unsurları da kaybetmekteyiz. Son yıllarda Samsun'da da gözlenen bu tarihi kayıplar, Kefeli Apartmanı gibi mevcut örnekleri daha değerli kılmaktadır.

İstanbul'da bulunan apartman duvar resimlerinin bir kısmında sanatçc imzası bulunmazken bir kısmında ise hem Türk hem de gayrimüslim sanatçıların imzasına rastlanmaktadır (Pınarbaşı, 2004:183). Kefeli Apartmanında ise sanatçı, imzasını "Kemal" olarak belirtmekte ve "1934, i̇stanbul" bilgilerini de sunmaktadır (Görsel 6). 1934 tarihi söz konusu iki resmin tamamlanış tarihini sunduğu tahmin edilse de verilen istanbul bilgisi iki ihtimali akla getirmektedir; Birinci, söz konusu iki manzaranın İstanbul'a ait olduğu bilgisi. Özellikle sol duvarda yer alan manzaranın Moda İskelesi'ne ait olması ve bir fotoğraftan kopyalanması bu olasılığı kuvvetlendirmektedir. İkincisi ise Kemal imzasına sahip sanatçının İstanbul'dan gelmiş olabileceğidir. Apartman inşası için kent dışından usta ve mimar getirtmek bu dönemde doğal bir süreç olarak kabul edilmektedir ve kent dışından gelen bu isimlere bir ressamın katılmıs olması da muhtemeldir.

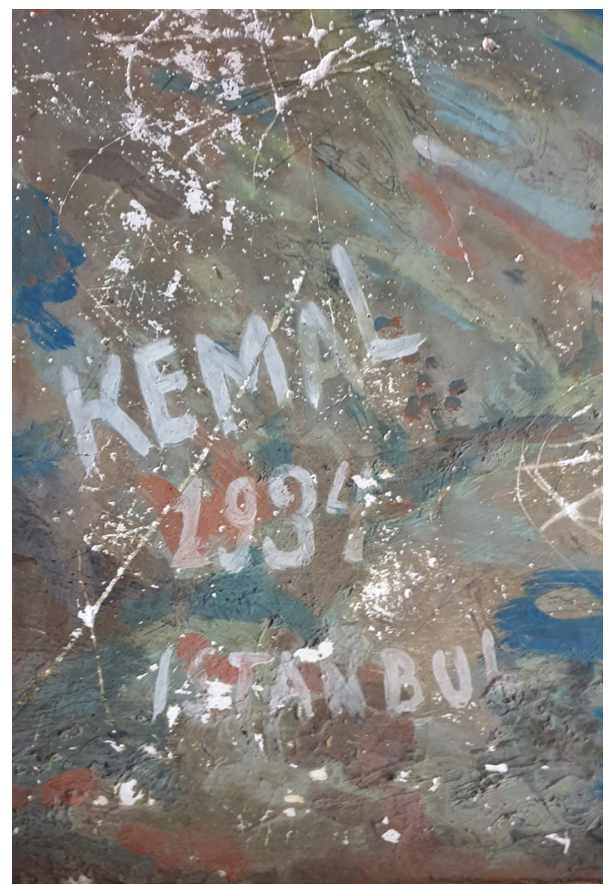

Görsel 6. Sağ Duvarda Kalan Duvar Resminde Sanatçı İmzası (E. Kolay, 2020)

Dışavurumcu bir anlayışla ele alındığı görülen söz konusu duvar resimlerinde renk kullanımı ve figürlerin pozisyonu betimlenen doğanın derinlik algısını artırmakta, bu bağlamda Türk resim sanatında özellikle Çallı Kuşağı'nın manzara resmiuygulamalarındaki temel özelliklerin tekrarlandığı görülmektedir. İinciduvarresmindetespitedebildiğimiz, XIX.yüzyıldaasker ressamlar tarafından sıklıkla tercih edilen fotoğraftan yararlanarak manzara resmi üretme tekniğinin bu vesile ile Cumhuriyet dönemine de intikal ettiğini söyleyebiliriz. 1920'li ve 30'lu yıllarda İstanbul'un gözde semtleri arasında yerini alan Moda'nın, taşra kenti Samsun'daki bir apartmanın 
giriş holü duvarını süslemesi ile XIX. yüzyılda Anadolu'nun bir köşesinde yer alan bir konağın tavan eteğini süsleyen Boğaziçi manzarası arasındaki bağlantı, sanatçı akışının İstanbul'dan yayııımı ile sınırlı olmalıdır. Bununla birlikte XIX. yüzyılda konakta yaşayan bir Anadolulu ile 1930'lu yıllarda kentin en modern apartmanında yaşayan kent sakini arasında "istanbul beğenisi ya da özlemi" sürekliliğinin mevcudiyeti de sorgulanabilir.

Özet ve sonuç olarak, Kefeli Apartmanı'nda bulunan iki duvar resminin XIX. yüzyılda gelişen kent temalı resim sanatının XX. yüzyıldaki uzantısı olarak yorumlamak gerekmektedir. Söz konusu eserlerin kentte moderni simgeleyen bir yapıda yer alması ise dönemin modern ile gelenek arasında sıkışıı̧ bir kitlesinin dışavurumu olarak okunabilir. 


\section{Kaynakça}

Akın, G. (20I0). "20. Yüzyıl Başında İstanbul: Toplumsal ve Mekânsal Farklılaşma”, Osmanlı Başkentinden Küreselleşen İstanbul'a: Mimarlık ve Kent, 1910-2010, İstanbul: Osmanlı Bankası Arşiv ve Araştırma Merkezi Yayınları, 20-30.

Arık, R. (1976). Batılılaşma Dönemi Anadolu Tasvir Sanatı, Ankara: Türkiye İş Bankası Kültür Yayınları.

Aslanoğlu, İ. (2010). Erken Cumhuriyet Dönemi Mimarlığı, 1923-1938, İstanbul: Bilge Kültür Sanat Yayınları.

Batur, A. (Haz.) (2003). M. Vedad Tek Kimlï̆inin İzinde Bir Mimar, İstanbul: Yapı Kredi Yayınları.

Bayraktar, M. S. (2016). Samsun'da Türk Devri Mimarisi, Samsun: Canik Belediyesi Yayınları.

Bozdoğan, S. (2008). Modernizm ve Ulusun Inşası Erken Cumhuriyet Türkiyesi'nde Mimari Kültür, (Çev. Tuncay Birkan), İstanbul: Metis Yayınları.

Demirarslan, D. (2016). “19. Yüzyıl Türk Sivil Mimarisinde Duvar Resmi Estetiği ve Istanbul Teması”, Mimarlık ve Yaşam Dergisi, I(I), I05-I25.

Derin Öncel, A. (20I4). Apartman. Galata'da Yeni Bir Konut Tipi, İstanbul: Kitap Yayınevi.

Duymaz, A. Ş. (2006). XIX. Yüzyılda Samsun'un Kentsel Gelişimine Dair Birkaç Mimari Örnek.C. Yılmaz (Ed.). Geçmişten Geleceğe Samsun, I. Kitap, Samsun. Samsun Büyükşehir Belediyesi Yayınları, 449-462.

Eyice, S. (198I). "XVIII. Yüzyılda Türk Sanatı ve Türk Mimarisinde Avrupa Neo-Klasik Üslubu”, Sanat Tarihi Yıllığı, (IX-X), I63-190.

Görgülü, T. (2016). “Apartman Tipolojisinde Geçmişten Bugüne; Kira Apartmanından "Rezidans'a” Geçiş”, TÜBA-KED, (14), I65-I78.

İstanbul Büyükşehir Belediyesi Atatürk Kitaplı̆̆ı, Katalog No: Krt, 016322.

Kuban, D. (1954). Türk Barok Mimari Hakkında Bir Deneme, ìstanbul: İstanbul Teknik
Üniversitesi Yayınları.

Osma, K. (2003). Cumhuriyet Dönemi Anıt Heykelleri (1923-1946), Ankara: Atatürk Araştırma Merkezi Yayınları.

Özakbaş, D. (2015). "İstanbul Konut Mimarisinin 1923-1940 Yılları Arasındaki Gelişim Süreci”, Thejournal of AcademicSocialScienceStudies, (40), s. 283-3I0.

Pınarbaşı, S. Ö. (2004). "Beyoğlu Apartmanlarında Bulunan Duvar Resimleri”, Geçmişten Günümüze Beyoğlu, I, İstanbul: Türkiye Anıt Çevre Turizm Değerlerini Koruma Vakfı ve Beyoğlu Belediyesi Ortak Yayını, s. I79-I84.

Renda, G. (1977). Batılılaşma Döneminde Türk Resim Sanatı, I700-/850, Ankara: Hacettepe Üniversitesi Yayınları.

Rizzo, J. A. (I 929). AnnuaireOriental, Constantinople: Imprimeri de l'AnnuaireOriental.

Tezer, N. (2017). 1930-1940 Yılları Arasında İstanbul'da İnşa Edilmiş Apartmanların Cephe Biçimlenişi, Yayınlanmamış Yüksek Lisans Tezi, İstanbul Teknik Üniversitesi, Fen Bilimler Enstitüsü, İstanbul.

Topal, C. (2006). Cumhuriyetin Illk Yıllarında Samsun Limanı. C. Yılmaz (Ed.). Geçmişten Geleceğe Samsun, I. Kitap, Samsun. Samsun Büyükșehir Belediyesi Yayınları, 327-33I.

Uğurlu, B. P. (2020). Anadolu'da Son Dönem Osmanlı Duvar Resimlerinde Kent İmgeleri, Konya: Literatürk Academia Yayınları. 